\title{
Further Studies on the Effect of Hypothalamic Lesions in the Sand Rat (Psammomys Obesus)
}

\author{
B.N. Brodoff, M.D., and Gutllermo Zebalios* \\ Departments of Medicine and Physiology, The New York Medical College, New York, USA
}

\begin{abstract}
Summary. Median eminence lesions, in the area of the arcuate nucleus, appear to decrease, one hour post oral glucose, blood glucose levels in hyperglycemic rats, independent of changes in weight.

Nouvelles observations quant à l'effet de lésions hypo. thalamiques chez le rat des sables (Psammomys obesus)

Résumé. Des lésions placéos au niveau du nucléus arcuatus semblent diminuer les taux de glucose sanguin observés une heure après une surcharge par voie orale chez les animaux par ailleurs hyperglycémiques.
\end{abstract}

Zusätzliche Beobachtungen der Folgen hypothalamischer Laesionen bei der Sandratte (Psammomys obesus)

Zusammenfassung. Laesionen in der Gegend des $\mathrm{Nu}$ cleus Arcuatus scheinen die nach einer Stunde nach Glucose per os erhaltenen Blutzuckerwerte bei hyperglykämischen Sandratten zu vermindern.

Key-words: Sandratte, Psammomys obesus, blood glucose, hypothalamus, lesions of hypothalamus, hyperglycemia.
In an attempt to establish a laboratory colony of the sand rat (Psammomys obesus), it was found that this animal develops a chow-induced diabetic syndrome [29]. This syndrome is characterized by hyperglycemia, elevated plasma insulin levels except during ketoacidosis, diminished extractable pancreatic insulin, glucosuria, and pathologic lesions including cataracts, $B$ cell degeneration, vacuolization of the pancreatic islet tissue and glycogen nephrosis $[13,14,25,20,11]$. The animals vary in their diabetogenic susceptibility $[14,24]$.

That starvation diminishes carbohydrate tolerance was first recognized by Claude Bernard [3], and has been since confirmed by a number of investigators $[32,2,17,35]$. The possible existence of a long acting contra-insulin starvation hormone from the anterior pituitary was considered over thirty years ago $[10,2]$. In white rats, $7 \mathbf{- 1 0}$ days are required for the development of starvation diabetes, these animals being notably resistant to the induction of experimental diabetes [17]. The effect of a preliminary feeding of carbohydrate in improving the glucose tolerance was first described in 1919 [15] and by Staub and Traugott [31, 34]. This effect has also been observed in the sand rat, with the blood sugar returning toward starvation levels within $6 \mathrm{~h}$ in this species (see below).

It has been known since the fundamental observation of B.A. Houssay and his collaborators [16], that removal of the anterior lobe of the pituitary greatly diminishes the severity of diabetes in pancreatectomized animals. F. G. Young, in his studies on metahypophyseal diabetes, established the concept that growth hormone (GH) might be the diabetes-inducing substance of the hypophysis [8].

In 1963 [28], it was shown that insulin-induced hypoglycemia was associated with a rapid rise in plasma GH levels which could be shut off by prompt Chile.

* Present address: The University of Chile, Santiago, glucose administration. Also, prolonged fasting in a normal subject was accompanied by a progressive rise in the plasma level of the hormone, subsequently turned off by feeding. The fasted sand rat with chemical diabetes has relatively low fasting and $4 \mathrm{~h}$ blood glucose values. It seemed possible, therefore, that GH was playing a role in the development of diabetes in the sand rat, since fasting and feeding in these intermittent feeders could provide continuous alternations of blood sugar levels as a stimulus to $\mathrm{GH}$ secretion.

Hypothalamic releasing factors for $\mathrm{GH}$ have been demonstrated $[27,18,21]$, as have hypothalamic glucoreceptors $[23,22,1]$. The possibility that an increased sensitivity of these receptors to a blood sugar fall, or to some other metabolic stimulus appearing in the course of starvation played a role in initiating the diabetic syndrome in the sand rat was considered by us; if this were so, interruption of the hypothalamohypophyseal reflex arc might have an ameliorative effect. Reflex secretion of GH in the rat appears to be blocked by lesions in the posterior median eminence [19]. Our earlier studies have suggested that this type of lesion may improve the diabetic glucose tolerance of the sand rat $[4,5]$.

This paper describes some characteristics of the oral glucose tolerance of 94 sand rats, and a correlative study of post-lesion histology, $1 \mathrm{~h}$ blood glucose levels after oral glucose, and weight, in 17 sand rats.

\section{Materials and Methods}

Sand rats trapped in Egypt, and others bred in captivity, were used. All animals received fresh vegetables (carrots and spinach) ad libitum, with no additional water available. They were kept in a separate room in the animal quarters kept at $78-82^{\circ} \mathrm{F}$ and $40-50 \%$ relative humidity. Glucose $300 \mathrm{mg} / \mathrm{ml} \mathrm{N}$ saline/100 g rat was administered orally by gavage after an overnight $(15-17 \mathrm{~h})$ fast, and glucose levels 
were measured in $20 \mu l$ of blood obtained from the tip of the tail. "Two and six hour fed" sand rats were fasted overnight, then given oral glucose two and six hours after feeding of vegetables, ground up with $\mathbf{N}$ saline, in a Waring blendor. "Two hour fed" white rats were treated in a similar manner but were fed a suspension of lab chow in saline also prepared in a Waring

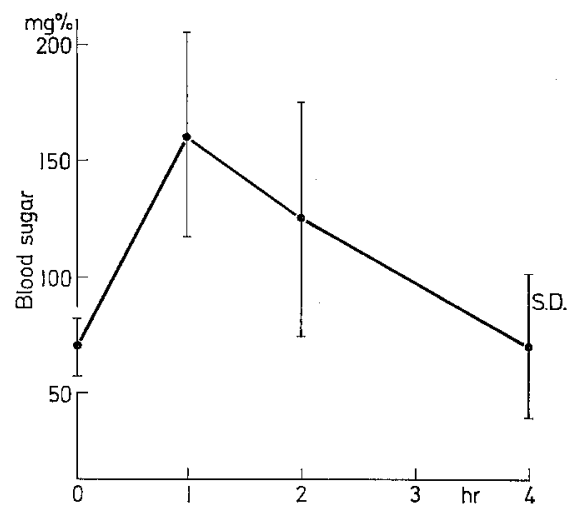

Fig. 1. Oral GTT in 94 sand rats with epoxylite, except for $0.4 \mathrm{~mm}$ at the tip. The animal's head was fixed in a C.A. Stoelting stereotaxic instrument and the incisor bar adjusted so that the surface of the animal's skull was perpendicular to the vertical zero of the instrument. Animals were anaesthetized with Avertin (25 mg/100 gm rat IP). The stereotaxic coordinates for the lesions were $F=4.8$ (except if noted otherwise) $\mathrm{H}=$ base +0.2 , placed in the midline. A current of 3 milliamperes (estimated) was passed for 30 sec. Animals were either decapitated terminally or, in some cases, died from other causes. Brains were fixed in $10 \%$ formalin and prepared for histological examination either by passage through alcohol and embedding in paraffin, or by freezing. Sections (15 $\mu$ thick for paraffin and $50 \mu$ for frozen) were stained for the most part with toluidine blue but $\mathrm{H} \& \mathrm{E}$, thionine and cresyl violet were also used. Histology was read blind (G.Z.).

\section{Results and Discussion}

The four hour oral glucose tolerance of 94 sand rats shows a peak at $1 \mathrm{~h}$, relatively high when compared to

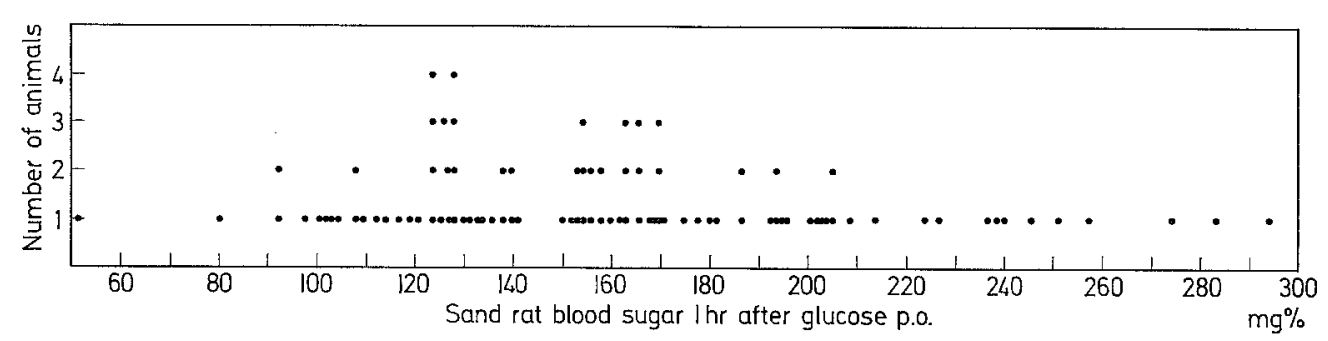

Fig. 2. Distribution of $1 \mathrm{~h}$ blood sugars in the sand rat (94 animals)

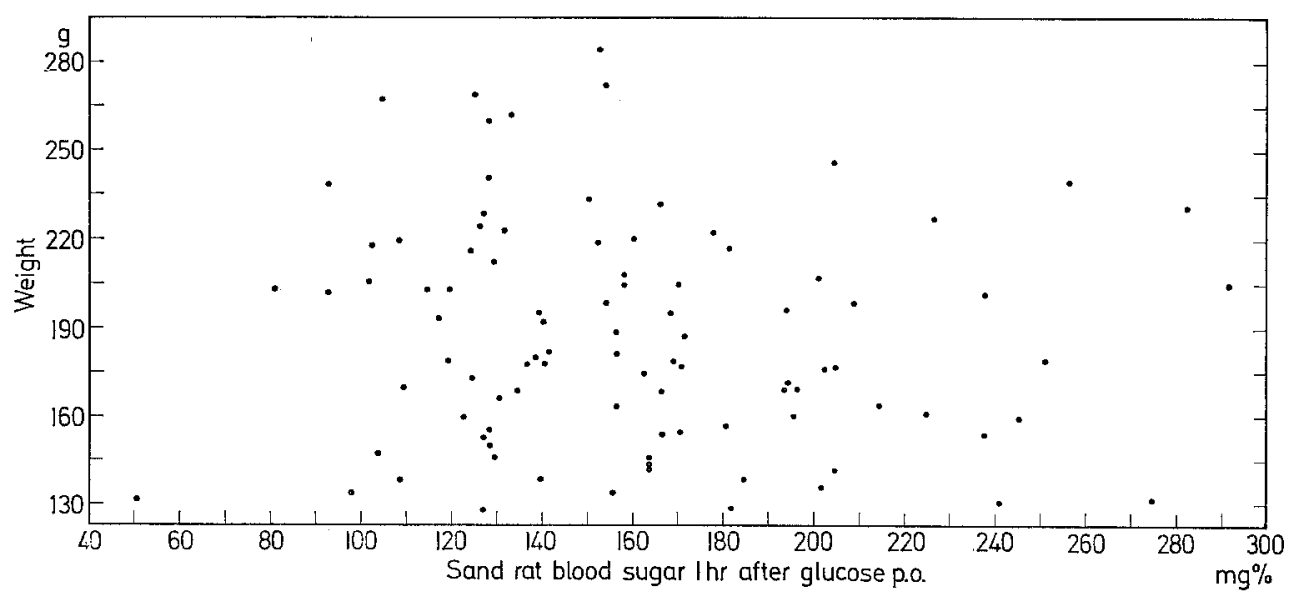

Fig. 3. Relationship to weight of $1 \mathrm{~h}$ blood sugar levels in the sand rat (94 animals)

blendor. Blood sugars were measured on the Technicon autoanalyzer using the standard ferricyanide microdetermination technique.

A radiofrequency lesion maker "Grass model LM3" was used for placing the stereotaxic lesions. It had a stainless steel electrode diameter of $0.3 \mathrm{~mm}$, insulated white rats, and low fasting and $4 \mathrm{~h}$ values. (Fig. 1). The distribution of one hour blood sugars appears to be unimodal but skewed, with many animals in the hyperglycemic range (Fig. 2). There is no correlation between weight and one hour blood sugars (Fig. 3). Information on body composition in the sand rat is 
unavailable at present. Prior feeding lowers the $1 \mathrm{~h}$ blood sugar somewhat in hyperglycemic sand rats, but not in white rats or normoglycemic sand rats (Table 1 ). Furthermore, this is throughly dissipated (within $6 \mathrm{~h}$ ) even in the hyperglycemic sand rat (Table 1). Although the mechanism of the Staub Traugott effect remains to be elucidated [33, 9], the hypophysis appears to be indispensable for this phenomenon [30]. ciated with a transitory drop in blood sugar (lasting 64 days) and the other animal demonstrated an electrode tract in the median eminence with questionable destruction of cells. Midline lesions in other areas of the anterior and posterior hypothalamus did not alter the blood sugar in 8 animals (Table 3 ).

There are a number of problems in the interpretation of these data. Since this study concerned a colony

Table 1. Blood sugar one hour after oral glucose

\begin{tabular}{|c|c|c|c|c|c|}
\hline & $\mathrm{N}$ & $15 \mathrm{~h}$ fast & $2 \mathrm{~h}$ fast & $6 \mathrm{~h}$ fast & $P$ \\
\hline $\begin{array}{l}\text { Hyperglycemic } \\
\text { SR }\end{array}$ & 15 & $196(37)^{\mathrm{a}}$ & $148(33)$ & & $<0.01$ \\
\hline $\begin{array}{l}\text { Normoglycemic } \\
\text { SR }\end{array}$ & 8 & $93(19)$ & $108(37)$ & & \\
\hline White Rats & 4 & $100(11)$ & $109(8)$ & & \\
\hline $\begin{array}{l}\text { Hyperglycemic } \\
\text { SR }\end{array}$ & $11^{\mathrm{b}}$ & $187(32)$ & & $176(30)$ & \\
\hline $\begin{array}{l}\text { Normoglycemic } \\
\text { SR }\end{array}$ & $11^{\mathrm{c}}$ & $115(14)$ & & $110(23)$ & \\
\hline
\end{tabular}

a Figures in parentheses are standard deviations

b 11 tests on 7 sand rats

c 15 tests on 9 sands rats.

Table 2. Lesions in arcuate nucleus

\begin{tabular}{|c|c|c|c|c|c|c|c|}
\hline S.R. & Sex & $\begin{array}{l}\text { Age } \\
\text { (months) }\end{array}$ & $\begin{array}{l}\text { Coordi- } \\
\text { nates } \\
(\mathrm{AP})\end{array}$ & Lesion & One hour B.S. & $\begin{array}{l}\text { Days } \\
\text { post } \\
\text { lesion }\end{array}$ & Weights \\
\hline $80 \mathrm{~A}$ & M & $\begin{array}{l}>6 \\
\text { (estimated) }\end{array}$ & 4.8 & Arcuate nuclei & $213(1)^{\mathrm{a}} / 95(2)$ & 24 & $195(1) / 189(2)$ \\
\hline 13 & $\mathbf{F}$ & $\begin{array}{l}>6 \\
\text { (estimated) }\end{array}$ & 4.8 & $\begin{array}{l}\text { Periventricular } \\
\text { extension of } \\
\text { arcuate nuclei } \\
\text { and VM nuclei }\end{array}$ & $215(1) / 96(2)$ & 14 & $219(1) / 209(2)$ \\
\hline 107 & $\mathrm{~F}$ & 6 & 4.8 & Arcuate nuclei & $\begin{array}{l}160(1) / 128(1) 1 \mathrm{~h} \\
197(1) / 110(1) 2 h^{b}\end{array}$ & 45 & $220(1) / 215(1)$ \\
\hline 84 & M & 17 & 4.8 & Arcuate nuclei & $168(1) / 111(1)$ & 23 & $196(1) / 182(1)$ \\
\hline 45 & M & 6 & 4.8 & Arcuate nuclei & $208(2) / 107(1)$ & 24 & $185(2) / 203(1)$ \\
\hline 89 & $\mathrm{~F}$ & 17 & 4.8 & $\begin{array}{l}\text { Periventricular } \\
\text { extension of arcuate } \\
\text { nucleus, arcuate } \\
\text { nucleus and VM nucleus }\end{array}$ & $238(1) / 116(4)$ & 81 & $202(1) / 193(4)$ \\
\hline 158 & $\mathbf{F}$ & 6 & 4.8 & $\begin{array}{l}\text { Arcuate nucleus } \\
\text { (unilateral) }\end{array}$ & $228(2) / 117(7)$ & 87 & $182(2) / 182(7)$ \\
\hline 61 & $\mathrm{~F}$ & 6 & 4.8 & $\begin{array}{l}\text { Arcuate nucleus } \\
\text { (unilateral) }\end{array}$ & $\begin{array}{c}201(1) / 119(3) ; 179(3) \\
(150)(6)\end{array}$ & $\begin{array}{l}64 \\
92\end{array}$ & $\begin{aligned} 209(1) / 201(3) ; 191(3) \\
(196)(6)\end{aligned}$ \\
\hline 54 & $\mathbf{F}$ & 10 & 4.8 & $\begin{array}{l}\text { No lesion? Electrode } \\
\text { tract along 3rd } \\
\text { ventricle }\end{array}$ & $125(1) / 150(4)$ & 54 & $271(1) / 242(4)$ \\
\hline
\end{tabular}

a Figures in parenthesis refer to number of determinations.

b Peak blood sugar value pre lesion was at $2 \mathrm{~h}$. The pattern of the glucose tolerance remained unchanged post lesion in other animals tested with peak values at $1 \mathrm{~h}$.

It would appear from the present study that lesions of the median eminence, in the area of the arcuate nucleus, lowered the one hour blood sugar in 7 of 9 animals independent of weight change (Table 2). Of the two animals that failed to respond, one animal had a small unilateral lesion in the arcuate nucleus asso- of wild animals and their offspring, the experimental subjects were of different age, sex and weight. In addition, the size of radio-frequency lesions varies, in our hands at least, perhaps as a result of instantaneous current drop when tissue is destroyed and coats the electrode. Furthermore there is some variability in the 
one hour blood sugar in individual sand rats. In order to evaluate this, 40 one hour determinations were performed on 15 hyperglycemic sand rats.

Arbitrarily setting $175 \mathrm{mg} \%$ as threshold for hyperglycemic levels and $140 \mathrm{mg} \%$ as the upper limit of normoglycemia, 3 of 40 determinations fell to normoglycemic levels. This compares with 3 of 43 in the lesioned group outside the arcuate nucleus and 19 of 39 in the group with lesions of the arcuate nucleus. Since all of the animals were handled in a similar manner, it would appear that lesions involving the arcuate nucleus tend to have a blood sugar lowering effect in the sand rat.

Confirmatory information of a role for the periventricular areuate system in the diabetic syndrome of these animals will be presented elsewhere [6]. The ventromedial nuclei are in close proximity to and extend alongside the midportion of the arcuate system, which growth hormone secretion. Endocrinology 70, 605 (1966).

2. Bergman, H.C., Drury, D.R.: Effect of feeding and fasting on sugar utilization of eviscerated rabbits. Proc. Soc. exp. Biol. 37, 414-417 (1937).

3. Bernard, C.: Leçons sur le diabète et la glycogénèse animale, p. 70. Paris, 1877.

4. Brodoff, B.N., Zeballos, G., Dorn, J.: Amelioration of the diabetic glucose tolerance of the sand rat after hypothalamic injury. Metabolism, 6, 744 (1967).

5. - - - A possible role for the central nervous system in sand rat diabetes. Excerpta medica international congress series No. 172, proceedings of the VIth congress of the Int. Diabetes Federation Stockholm, Excpt. Med. Foundation, Amsterdam, p. 823 (1969).

6. Brodoff, B. N., Kagan, A., Hagedoorn, J., and Slotnik, B.: The effect of hypothalamic lesions in the sand rat maintained on a high fat diet.

7. Cahill, G.F.: Pathophysiology of diabetes. Med. Clin. N. Amer. 49, 881-892 (1965).

8. Cotes, P.M., Reid, E., Young, F.G.: Nature (Lond.) 164, 992 (1949).

Table 3. Lesions outside arcuate nucleus

\begin{tabular}{|c|c|c|c|c|c|c|c|}
\hline S.R. & Sex & $\begin{array}{l}\text { Age } \\
\text { (months) }\end{array}$ & $\begin{array}{l}\text { Coordi- } \\
\text { nates } \\
(\mathrm{AP})\end{array}$ & Lesion & One hour B.S. & $\begin{array}{l}\text { Days } \\
\text { post } \\
\text { lesion }\end{array}$ & Weights \\
\hline 65 & $\mathrm{~F}$ & 14 & 4.8 & Mesencephalon & $187(1)^{\mathrm{a} / 197(4)}$ & 87 & $186(1) / 155(4)$ \\
\hline 50 & $\mathrm{~F}$ & 11. & 4.8 & Mammillary bodies & $170(1) / 176(3)$ & 63 & $206(1) / 213(3)$ \\
\hline 19 & M & 12 & 4.8 & Mammillary bodies & $181(1) / 170(4)$ & 64 & $218(1) / 177(4)$ \\
\hline $90 \mathrm{~B}$ & $\mathbf{F}$ & 14 & 4.8 & $\begin{array}{l}\text { Posterior hypothala- } \\
\text { mus above } \\
\text { mammillary bodies }\end{array}$ & $268(1) / 202(3)$ & 54 & $254(1) / 228(3)$ \\
\hline $99 \mathrm{~B}$ & $\mathrm{~F}^{\mathrm{r}}$ & 22 & 4.8 & $\begin{array}{l}\text { Thalamus at } \mathrm{n} \text {. } \\
\text { reuniens }\end{array}$ & $194(1) / 189(3)$ & 51 & $173(1) / 172(3)$ \\
\hline 67 & $\mathbf{F}$ & 16 & 4.8 & $\begin{array}{l}\text { Posterior hypothala- } \\
\text { mus dorsal to VMN }\end{array}$ & $164(2) / 163(3)$ & 26 & $225(2) / 195(3)$ \\
\hline 23 & $\mathbf{F}$ & 12 & 4.82 & Anterior hypothalamus & $211(2) / 197(6)$ & 51 & $158(2) / 160(6)$ \\
\hline 96 & $\mathbf{F}$ & 16 & 4.89 & Anterior hypothalamus & $159(2) / 145(6)$ & 51 & $157(2) / 140(6)$ \\
\hline
\end{tabular}

a Figures in parenthesis refer to number of determinations

is considered by some to be the final common neuroendocrine path [36]. In a study reported on at this symposium bilateral lesions of the ventromedial nucleus were also associated with a reversion toward normal of hyperglycemic blood sugar values in another diabetic species, the $d b$ mouse [37].

Our decision to investigate central neurogenic influences on sand rat metabolism was based on earlier studies on growth hormone physiology in other species $[2,10,8,28,30]$, and also on the response of these animals to fasting and feeding [26,7]. The mechanism of these neural effects remains to be elucidated.

Acknowledgements. The authors are most grateful to Dr. Harry Hoogstraal (NAMRU-3), the United States Navy, and Dr. K. Schmidt Nielsen for a supply of sand rats. This work was supported in large part by USPHS Grant \# 10675 and also \# NB 06624 .

\section{References}

1. Abrams, R.L., Parker, M.L., Blanco, S., Reichlin, S., Danghaday, W.H.: Hypothalamic regulation of
9. Metz, R., Friedenberg, R. : Investigation of the StaubTraugott effect. Diabetes 18, Suppl. 1, 327 (1969).

10. Greoley, P.O.: Proc. Soc. exp. Biol. 32, 1070 (1935). 11. Hackel, D.B., Schmidt-Nielsen, K., Haines, H.B., Mikat, E.: Diabetes mellitus in the sand rat (Psammomys obesus). Lab. Invest. 14, 200-207 (1965).

12. - Mikat, E., Lebovitz, H.E., Schmidt-Nielsen, K. Diabetes mellitus like disease in sand rats (Psammomys obesus). Diabetes (proceedings of the sixth congress of the International Diabetes Federation, J. Ostman, Excpt. Med. Foundation, Amsterdam, p. 800, 1969.

13. - Frohman, L.A., Mikat, E., Lebovitz, H.E., Schmidt-Nielsen, K., Kinney, T.D. Effect of diet on the glucose tolerance and plasma insulin levels of the sand rat (Psammomys obesus) Diabetes 15, 105-114 (1966).

14. $-\ldots+\ldots$ Review of current studies on effect of diet on the glucose tolerance of the sand rat (Psammomys obesus). Ann. N.Y. Acad. Sci. 131, $459-463$ (1966).

15. Hamman, Hirschman: Johns Hopk. Hosp. 30, 306 (1919).

16. Houssay, B.A., Biasotti, A.: C.R. Soc. Biol. 104, 407; $105,121,124(1930)$.

17. Ingle, D.J.: Experimental glycosuria in the rat. Recent Progr. Hormone Res. 21, 229 (1948). 
18. Katz, S., Krulich, L., MeCann, S.M.: Effect of insulin-induced hypoglycemia on the concentration of GHRF in plasma and hypothalamus of the rat. Fed. Proc. 25, 191 (1966).

19. Krulich, L., Dharwol, A.P.S., MeCann, S.M.: Hypothalamic control of growth hormone (GH) secretion. Abstracts. Annual Meeting of the Endocrine Society 21 (1965).

20. Like, A. A., Miki, E. : Diabetic syndrome in sand rats. IV. Morphologic changes in islet tissue. Diabetologia 3, 143-166 (1967).

21. McCann, S.M., Porter, J.C.: Hypothalamic pituitary stimulating and inhibiting hormones. Physiol. Rev. $49,240-284$ (1969).

22. Marshall, W.S., Barnett, R.J., Mayer, J.: Hypothalamic lesions in goldthioglucose injected mice. Proc. Soc. exp. Biol. (N.Y.) 9, 240 (1955).

23. Mayer, J.: Physiol. Rev. 33, 472 (1953).

24. Miki, E., Like, A.A., Steinke, J., Soeldner, J.S.: Diabetic syndrome in sand rats. II. Variability and association with diet. Diabetologia 3, 135-139 (1967).

25. - - Soeldner, J.S., Steinke, J., Cahill, G.F., Jr.: Acute ketotic-type diabetic syndrome in sand rats (Psammomys obesus) with special reference to the pancreas. Metabolism 15, $749-760$ (1966).

26. Neel, J.V.: Diabetes mellitus: a 'thrifty' genotype rendered detrimental by 'progress' ? Amer. J. Human. Genet. 14, 353 (1962).

27. Reichlin, S.: Growth and the hypothalamus. Endocrinology 67, $760(1960)$.

28. Roth, J., Glick, S.M., Yalow, R.S., Berson, S.A.: Hypoglycemia: A potent stimulus to secretion of growth hormone. Science 140, $987-988$ (1963).
29. Schmidt-Nielsen, K., Haines, H.B., Hackel, D.B. Diabetes mellitus in the sand rat induced by standard diets. Science 143, 689-690 (1964).

30. Soskin, S., Mirsky, I.A., Zimmerman, L.M., Heller R.C.: Indispensability of the hypophysis to the StaubTraugott phenomenon. Amer. J. Physiol. 116, 148 (1936).

31. Straub, H.: Untersuchungen über den Zuckerstoffwechsel des Menschen. I. Mitteilung: Über das Verhalten des Blutzuckers nach peroraler Zufuhr kleiner Glukosemengen. Z. klin. Med. 91, 44 (1921).

32. Sweeney, : Arch. Intern. Med. 40, 818 (1927).

33. Szabo, A., Maier, J., Szabo, O., Camerini-Davalos, R.: Improved glucose disappearance following repeated glucose administration. Diabetes 18, 232 (1969).

34. Traugott, K.: Über das Verhalten des Blutzuckerspiegels bei wiederholter und verschiedener Art enteraler Zuckerzufuhr und dessen Bedeutung für die Leberfunktion. Klin. Wschr. 1, 892 (1922).

35. Unger, R.H., Eisentraut, A.M., Madison, L.L.: The effects of total starvation upon the levels of circulating glucagon and insulin in man. J. clin. Invest. 42, $1031-1039$ (1963).

36. Reichlin, S.: Neuroendocrinology. Now Engl. J. Med. medicine 269, 1182 (1963).

37. Coleman, D.L., Hummel, K.P.: The effects of hypothalamic lesions in genetically diabetic mice. Diabeto logia 6, 263-267 (1970).

Dr. B.N. Brodoff

Department of Medicine

The New York Medical College

106th St. and Fifth Avenue

New York City 10029, N.Y.

USA 